\title{
An Implementation of Profile Matching Method to Determine Agricultural Crops that Suit the Land
}

\author{
Aziz Fuady Negarawan ${ }^{1}$, Maria Ulfah Siregar ${ }^{1,2, *}$, Agung Fatwanto ${ }^{1,2}$ \\ M. Didik R. Wahyudi ${ }^{1}$ \\ ${ }^{1}$ Department of Informatics, Undergraduate Program, UIN Sunan Kalijaga Yogyakarta \\ ${ }^{2}$ Department of Informatics, Magister Program, UIN Sunan Kalijaga Yogyakarta, Indonesia \\ ${ }^{*}$ Corresponding author. Email: maria.siregar@uin-suka.ac.id
}

\begin{abstract}
The suitability of land conditions and crops is one of the factors that affect agricultural productivity. To get maximum results, agricultural crops must be planted on land that has the right conditions for crops to grow optimally. Lack of knowledge about land characteristics often makes farmers grow crops that are not suitable for their land so that the productivity is not optimal. To make it easier to determine suitable crops, a decision support system is needed to provide plant recommendations based on land conditions by applying the Profile Matching method. This method is broadly a process of comparing the actual data value of a profile to be assessed with the expected profile value, so that differences in competence can be known. There are two aspects used in this research, namely the physical aspect of the soil and the chemical aspect of the soil. There are 13 criteria used for the plant recommendation, namely temperature, rainfall, humidity, drainage, texture, cation exchange capacity, base saturation, $\mathrm{pH} \mathrm{H2O}$, organic $\mathrm{C}$, alkalinity, slope, erosion, and inundation. The result is an alternative decision support system to provide an alternative ranking of what plants are suitable to be planted on certain land. Data from the evaluation of the Profile Matching method show an accuracy rate of $77.94 \%$, a recall rate of $77.94 \%$, and a precision of $100 \%$.
\end{abstract}

Keywords: Land Suitability, Agricultural Productivity, Decision Support System, Recommendation, Alternative Ranking

\section{INTRODUCTION}

In this era of globalization, human life is required to be more competitive in various fields, one of which is in the field of agriculture. As an agricultural country, many Indonesian are part of the ongoing agriculture, either directly or indirectly. Fortunately, Ministry of Agriculture of our country has also makes use social media to share information about agriculture policies and listen information from community [1].

The productivity of food crops in Bantul Regency from 2013 to 2018 has increased and decreased interchangeably. This shows that the harvest yield is less stable in Bantul Regency. The productivity is influenced by several factors and one of them is the level of suitability of agricultural land in Bantul Regency. To get maximum results, agricultural crops must be planted on land whose conditions are in accordance with what plants need to grow optimally. Lack of knowledge of land characteristics often makes farmers plant crops that are not suitable for their land so that productivity is not optimal. For this reason, a decision support system is needed to assist the Bantul Regency Agriculture Officer in providing crop recommendations to farmers.

The method used in making decisions on the selection of agricultural crops that are suitable with the land is Profile Matching. This method was chosen because there is an ideal predictor level that must be met, not a minimum level that must be passed [2]. In this case the condition of the land is used as a benchmark for obtaining alternative plants with criteria that are as close as possible to the condition of the land.

In this decision support system we used two aspects that relate to plants [3], namely physical aspects and chemical aspects. From these two aspects, it is divided 
into 13 criteria that are used to determine plant recommendations that are suitable for the land. The criteria used can be seen in Table 1 below.

Table 1. Criteria

\begin{tabular}{|l|l|}
\hline \multicolumn{2}{|c|}{ Criteria } \\
\hline A1 & Temperature \\
\hline A2 & Rainfall \\
\hline A3 & Humidity \\
\hline A4 & Drainage \\
\hline A5 & Texture \\
\hline A6 & Cation Exchange Capacity \\
\hline A7 & Base Saturation \\
\hline A8 & pH H $\mathrm{O}^{-}$ \\
\hline A9 & Organic C \\
\hline A10 & Alkalinity \\
\hline A11 & Slope \\
\hline A12 & Erosion \\
\hline A13 & Inundation \\
\hline
\end{tabular}

The criteria for the physical aspect consist of temperature, rainfall, humidity, drainage, texture, slope, erosion, and inundation. The criteria for the chemical aspect consist of clay cation exchange capacity, base saturation, $\mathrm{pH} \mathrm{H} 2 \mathrm{O}$, organic $\mathrm{C}$, and alkalinity [4].

The usage of both aspects and 13 criteria are the differences of our research with others [5], [6]. By using these criteria, hopefully the plant recommendation will be suitable as much to the land. In [5] the researchers used Simple Additive Weighting (SAW) to process recommendation of crops and the number of criteria is six. The criteria are temperature, air pressure, wind velocity, humidity, rainfall, and altitude. Promethee was used instead in [6] to raise the recommendation of crops. In their research, there are 12 criteria. Our criteria that are not used in [6] are erosion, inundation, clay cation exchange capacity, base saturation, and organic

\section{METHOD}

First of all, literature study was conducted to obtain information about the research to be carried out. This study was conducted by reading and studying references in the form of scientific journals, theses, and books. Literature studies are also carried out using internet media to find data and information related to the object of research.

The researcher collected data by interview and literature study. Interviews were conducted in the form of questions and answers with experts from the Department of Agriculture to obtain data and information needed in research. Literature study was carried out to collect secondary data, namely from the Land Evaluation Technical Manual by BBSDLP as well as from the BMKG and BPTP Yogyakarta websites.

From the results of data collection, then the system is developed using the extreme programming method of the
System Development Life Cycle (SDLC) model. The stages of this method are Planning, Design, Coding, and Testing.

Next is the evaluation phase. The evaluation phase is carried out using a confusion matrix validation to calculate the accuracy of the series of activities that have been carried out.

\subsection{Decision Support System}

Decision Support System (DSS) is a system to provide problem solving skills and communication skills for problems with semi-structured and unstructured conditions. This system is used to help make decisions in semi-structured and unstructured situations [7].

DSS is a system to provide data management functions based on a certain model, so that users of the system can choose the best alternative decisions. The thing that needs to be emphasized here is that the decision support system is not a decision-making tool, but to help decision makers about a problem more quickly and accurately [8]

\subsection{Profile Matching}

Profile Matching is a decision-making mechanism by assuming that there is an ideal level of predictor variables that must be met by the subject under study, not a minimum level that must be met or passed [2].

The Profile Matching method is broadly a process of comparing the actual data value of a profile to be assessed with the expected profile value, so that differences in competence (also called gaps) can be known [9]. Here are some steps and formulation of the calculation method of Profile Matching:

\subsubsection{Weighting}

This phase will be determined the weight value of each aspect of using weights gap. Gap is the difference between the value of the aspect and the target value. It can be obtained by Equation 1:

$$
\text { Gap = Aspect Value }- \text { Target Value }
$$

\subsubsection{Core and Secondary Factor}

This stage determines the weight value gap necessary criteria, each criterion grouped into two groups: core factor and the secondary factor.

\subsubsection{Core Factor}

Core factor is the aspect most needed. The Equation 2 below is to calculate the core factor.

$N F C=\frac{\sum_{i=1}^{n} N C}{\sum_{i=1}^{n} I C}$

NCF: Core Factor Value 


\section{NC: Total Weight Core Factor \\ IC: Total Item Core Factor}

\subsubsection{Secondary Factor}

Secondary factors are the items other than that of the core aspects of factors. The formula for calculating the secondary factor is shown on Equation 3 as follows:

$$
\begin{aligned}
& N S F=\frac{\sum_{i=1}^{n} N S}{\sum_{i=1}^{n} I S} \\
& N C F=\frac{\sum_{i=1}^{n} N C}{\sum_{i=1}^{n} I C}
\end{aligned}
$$

NSF: Secondary Factor Value

NS: Total Weight Secondary Factor

IS: Total Item Secondary Factor

\subsubsection{Total Value Calculation}

From the calculation of core factors and secondary factors of every aspect, and then calculated the total value of each aspect of the estimated effect on the performance of each profile. To calculate the total value of each aspect, the following Equation 4 is used.

$N=(x) \% N C F+(x) \% N S F$

$\mathrm{N}$ : Total value of each aspect

NCF: Average Core Factor

NSF: Average Secondary Factor

$\mathrm{X} \%$ : Percentage value is entered

\subsubsection{Ranking}

The final result of the profile matching process is a ranking which refers to the calculation results shown by this Equation 5:

Ranking $=(\mathrm{x}) \% \mathrm{NMA}+(\mathrm{x}) \mathrm{NSA}$

NM: Total value of the Main Aspect criteria

NSA: Total score of the Supporting Aspect criteria

(x) $\%$ : Percent value entered

\subsection{Land}

Land is part of a landscape that includes the notion of the physical environment including climate, topography/relief, soil, hydrology, and even natural vegetation, all of which have the potential to affect land use [3].

\subsection{Land characteristics}

Land characteristics are land properties that can be measured or estimated. Land characteristics are: air temperature, rainfall, dry period, humidity, drainage, texture, coarse material, soil depth, peat thickness, peat maturity, clay cation exchange capacity, base saturation, $\mathrm{pH} \mathrm{H} 2 \mathrm{O}$, organic C, salinity, alkalinity, depth of sulfidic material, slope, erosion hazard, inundation, rock surface, and rock outcrop [3].

\subsection{Land Suitability}

Land suitability is the suitability of a plot of land for a particular use. The suitability of the land can be assessed for current conditions or after improvements have been made. Specifically, land suitability is the suitability of the physical and chemical properties of a land for farming or certain commodities. Physical properties are climate, soil, topography, hydrology and/or drainage, while chemical properties are $\mathrm{pH}$, base saturation, and micro nutrients [3].

\subsection{Confusion Matrix}

Confusion Matrix is a method used to calculate the accuracy of the concept of data mining or decision support systems. Based on the confusion matrix, the level of precision, recall, and accuracy can be measured. Equation for these three measurements are given on Equation 6-8. Precision is the level of accuracy of information requested by data and system users. Recall is the success of the system in finding back information. While accuracy is the closeness of the measurement of the quantity to the actual value. Table 2 shows the confusion matrix formula.

\begin{tabular}{|c|c|c|c|}
\hline & & \multicolumn{2}{|c|}{ Real Value } \\
\hline & & True & False \\
\hline \multirow{2}{*}{$\begin{array}{c}\text { Prediction } \\
\text { Value }\end{array}$} & True & $\begin{array}{l}\text { TP (True } \\
\text { Positive) } \\
\text { Correct Result }\end{array}$ & $\begin{array}{l}\text { FP (False Positive) } \\
\text { Unexpected Result }\end{array}$ \\
\hline & False & $\begin{array}{l}\text { FN (False } \\
\text { Negative) } \\
\text { Missing Result }\end{array}$ & $\begin{array}{l}\text { TN (True Negative) } \\
\text { Correct absence of } \\
\text { result }\end{array}$ \\
\hline
\end{tabular}

Table 2. Confusion Matrix

Precision $=\frac{T P}{T P+f p} * 100 \%$

Recall $=\frac{T P}{T P+F N} * 100 \%$

Accuracy $=\frac{T P+T N}{T P+T N+F P+F N} * 100 \%$

Measurement of accuracy can be done after matching the data obtained from manual calculations and system calculations. According to [10], the standard accuracy of the measurement results are as follows:

$\begin{aligned} 90 \%-100 \% \text { accuracy } & =\text { Excellent Classification } \\ 80 \%-90 \% \text { accuracy } & =\text { Best Classification } \\ 70 \%-80 \% \text { accuracy } & =\text { Fair Classification } \\ 60 \%-70 \% \text { accuracy } & =\text { Poor Classification } \\ 50 \%-60 \% \text { accuracy } & =\text { Failure }\end{aligned}$




\section{RESULTS AND DISCUSSION}

\subsection{System Description}

This system was created with the aim to help determining plants that are suitable for land in Bantul Regency. In determining plants, this system uses the calculation of the Profile Matching method. The system will sort the suitability of plants to the land based on the final value, from the largest to the smallest. This system runs on a web platform, and is built using the PHP programming language, CodeIgniter framework, and MySQL database.

\subsection{Calculation of the Profile Matching Method}

The following is an example of calculation results of plant and land suitability using the Profile Matching method.

Table 5 shows the calculation results of gap mapping from Table 3 and Table 4. In this paper we simulate for Bambanglipuro area. Moreover, only five criteria are shown for the sake of limited number of pages.

Table 6 shows the weighting results that based on gap mapping results in Table 5. The weight for gap 0 is 5 , the weight for gap 1 is 4.5 , and so on until gap -4.

Table 7 shows the calculation results of profile matching based on the total value of core factor and secondary factor from both aspects. Equation 2-4 are used to obtain values shown on Table 7. In this research, we defined $\mathrm{x}=55$ for core factor, and $\mathrm{x}=45$ for secondary factor. These values for $\mathrm{xs}$ are used in Equation 4.

Table 8 shows the result of crop ranking based on the final value of profile matching. The greater the final value indicates that the alternative is more suitable for the land. Equation 5 is used here with values for xs are 52.5 for core factor, and 47.5 for secondary factor. In other research, 60 is used for core/ main factor, and 40 is used for secondary factor [10].

All of xs' values used here are based on recommendation from the Bantul Regency Agriculture Officer. Values for core factor are bigger than the ones for secondary factor.

Table 3. Crop alternative criteria value

\begin{tabular}{|l|c|c|c|c|c|c|}
\hline \multicolumn{1}{|c|}{ Crop Name } & $\mathbf{A 1}$ & $\mathbf{A 2}$ & $\mathbf{A 3}$ & $\mathbf{A 4}$ & $\ldots$ & $\mathbf{A 1 3}$ \\
\hline Peanut & 3 & 2 & 4 & 3 & $\ldots$ & 1 \\
\hline Corn & 2 & 3 & 5 & 3 & $\ldots$ & 1 \\
\hline Cassava & 3 & 3 & 4 & 3 & $\ldots$ & 1 \\
\hline Paddy & 3 & 4 & 4 & 2 & $\ldots$ & 1 \\
\hline Soya Bean & 2 & 2 & 4 & 3 & $\ldots$ & 1 \\
\hline Sweet Potato & 2 & 3 & 4 & 3 & $\ldots$ & 1 \\
\hline Shallot & 2 & 1 & 5 & 3 & $\ldots$ & 1 \\
\hline $\begin{array}{l}\text { Red Chili } \\
\text { Pepper }\end{array}$ & 2 & 2 & 4 & 3 & $\ldots$ & 1 \\
\hline
\end{tabular}

Table 4. Land criteria value

\begin{tabular}{|l|c|c|c|c|c|c|}
\hline \multicolumn{1}{|c|}{ Land } & A1 & A2 & A3 & A4 & $\ldots$ & A13 \\
$\begin{array}{l}\text { Kec. } \\
\text { Bambanglipuro }\end{array}$ & 3 & 5 & 4 & 2 & $\ldots$ & 2 \\
\hline
\end{tabular}

Table 5. Gap mapping results

\begin{tabular}{|l|c|c|c|c|c|c|}
\hline \multicolumn{1}{|c|}{ Crop Name } & $\mathbf{A 1}$ & $\mathbf{A 2}$ & $\mathbf{A 3}$ & $\mathbf{A 4}$ & $\ldots$ & $\mathbf{A 1 3}$ \\
\hline Peanut & 0 & -3 & 0 & 1 & $\ldots$ & -1 \\
Corn & -1 & -2 & 1 & 1 & $\ldots$ & -1 \\
Cassava & 0 & -2 & 0 & 1 & $\ldots$ & -1 \\
Paddy & 0 & -1 & 0 & 0 & $\ldots$ & -1 \\
Soya Bean & -1 & -3 & 0 & 1 & $\ldots$ & -1 \\
Sweet Potato & -1 & -2 & 0 & 1 & $\ldots$ & -1 \\
Shallot & -1 & -4 & 1 & 1 & $\ldots$ & -1 \\
Red Chili & -1 & -3 & 0 & 1 & $\ldots$ & -1 \\
Pepper & &
\end{tabular}

Table 6. Weighting results

\begin{tabular}{|l|c|c|c|c|c|c|}
\hline \multicolumn{1}{|c|}{ Crop Name } & A1 & A2 & A3 & A4 & $\ldots$ & $\mathbf{A 1 3}$ \\
\hline Peanut & 5 & 2 & 5 & 4.5 & $\ldots$ & 4 \\
Corn & 4 & 3 & 4.5 & 4.5 & $\ldots$ & 4 \\
Cassava & 5 & 3 & 5 & 4.5 & $\ldots$ & 4 \\
Paddy & 5 & 4 & 5 & 5 & $\ldots$ & 4 \\
Soya Bean & 4 & 2 & 5 & 4.5 & $\ldots$ & 4 \\
Sweet Potato & 4 & 3 & 5 & 4.5 & $\ldots$ & 4 \\
Shallot & 4 & 1 & 4.5 & 4.5 & $\ldots$ & 4 \\
Red Chili Pepper & 4 & 2 & 5 & 4.5 & $\ldots$ & 4 \\
\hline
\end{tabular}

Table 7. Calculation results

\begin{tabular}{|c|c|c|c|c|c|}
\hline \multirow{2}{*}{$\begin{array}{l}\text { Crop } \\
\text { Name }\end{array}$} & \multicolumn{3}{|c|}{ Physical Aspect } & \multirow{2}{*}{$\cdots$} & \multirow{2}{*}{$\begin{array}{c}\text { Profile } \\
\text { Matching } \\
\text { Final } \\
\text { Score } \\
\end{array}$} \\
\hline & $\begin{array}{c}\text { Core } \\
\text { Factor }\end{array}$ & $\begin{array}{c}\text { Secondary } \\
\text { Factor }\end{array}$ & $\begin{array}{l}\text { Total } \\
\text { Value }\end{array}$ & & \\
\hline Peanut & 4.083 & 5.000 & 4.496 & $\ldots$ & 4.670 \\
\hline Corn & 4.000 & 4.750 & 4.338 & $\ldots$ & 4.551 \\
\hline Cassava & 4.250 & 5.000 & 4.588 & $\ldots$ & 4.546 \\
\hline Paddy & 4.500 & 5.000 & 4.725 & $\ldots$ & 4.719 \\
\hline $\begin{array}{l}\text { Soya } \\
\text { Bean }\end{array}$ & 3.917 & 5.000 & 4.404 & $\ldots$ & 4.622 \\
\hline $\begin{array}{l}\text { Sweet } \\
\text { Potato }\end{array}$ & 4.250 & 5.000 & 4.588 & $\cdots$ & 4.683 \\
\hline Shallot & 3.667 & 5.000 & 4.267 & $\ldots$ & 4.449 \\
\hline $\begin{array}{l}\text { Red } \\
\text { Chili } \\
\text { Pepper }\end{array}$ & 3.917 & 5.000 & 4.404 & $\cdots$ & 4.622 \\
\hline
\end{tabular}

Table 8. Calculation results

\begin{tabular}{|c|l|c|c|}
\hline Rank & Crop Name & $\begin{array}{c}\text { Profile Matching } \\
\text { Final Score }\end{array}$ & $\begin{array}{c}\text { Land } \\
\text { Suitability }\end{array}$ \\
\hline 1 & Paddy & 4.719 & Quite Suitable \\
\hline
\end{tabular}




\begin{tabular}{|c|l|c|c|}
\hline 2 & $\begin{array}{l}\text { Sweet } \\
\text { Potato }\end{array}$ & 4.683 & Quite Suitable \\
\hline 3 & Peanut & 4.670 & Quite Suitable \\
\hline 4 & Soya Bean & 4.622 & Quite Suitable \\
\hline 5 & $\begin{array}{l}\text { Red Chili } \\
\text { Pepper }\end{array}$ & 4.622 & Quite Suitable \\
\hline 6 & Corn & 4.551 & Quite Suitable \\
\hline 7 & Cassava & 4.546 & Quite Suitable \\
\hline 8 & Shallot & 4.449 & Quite Suitable \\
\hline
\end{tabular}

\begin{tabular}{|l|c|c|c|}
\hline $\begin{array}{l}\text { Kec. } \\
\text { Banguntapan }\end{array}$ & 6 & 2 & 8 \\
\hline Kec. Dlingo & 6 & 2 & 8 \\
\hline Kec. Imogiri & 5 & 3 & 8 \\
\hline Kec. Jetis & 5 & 3 & 8 \\
\hline Kec. Kasihan & 6 & 2 & 8 \\
\hline Kec. Kretek & 8 & 0 & 8 \\
\hline Kec. Pajangan & 8 & 0 & 8 \\
\hline Kec. Pandak & 6 & 2 & 8 \\
\hline Kec. Piyungan & 5 & 3 & 8 \\
\hline Kec. Pleret & 5 & 3 & 8 \\
\hline Kec. Pundong & 6 & 2 & 8 \\
\hline Kec. Sanden & 6 & 2 & 8 \\
\hline Kec. Sedayu & 8 & 0 & 8 \\
\hline Kec. Sewon & 6 & 2 & 8 \\
\hline Kec. Srandakan & 6 & 2 & 8 \\
\hline \multicolumn{1}{|c|}{ Total } & 106 & 30 & 136 \\
\hline
\end{tabular}
recall. Table 9 is the results of the comparison of plant rankings based on the system and manual calculations of each land.

Based on Table 9, 106 data match (TP) and 30 data does not match (FN). Total is 136 data.

Furthermore, the calculation of precision, recall, and accuracy on each land were performed using Equation 6, 7 , and 8 .

Precision $=\frac{T P}{T P+f p} * 100 \%=\frac{6}{6+0} * 100 \%=100 \%$

Recall $=\frac{T P}{T P+F N} * 100 \%=\frac{6}{6+2} * 100 \%=75 \%$

Accuracy $=\frac{T P+T N}{T P+T N+F P+F N} * 100 \%=\frac{6+0}{6+0+0+2} * 100 \%=$ $75 \%$

The results of the calculation can be seen in Table 10 .

Based on calculations that have been done, it can be seen at $100 \%$ precision level, the recall level of $77.94 \%$, and an accuracy of $77.94 \%$ in a decision support system that has been built. The accuracy of this system is higher than [5] with accuracy of $73.33 \%$. Based on [10], this decision support system is measured as fair classification.

These results indicate that DSS has adaptive and flexible properties which can be applied in all situations, including the process of providing crops recommendations. However, the application of the DSS method not only helps recommendations more quickly, but also accurately.

Table 9. Ranking comparison results

\begin{tabular}{|l|c|c|c|}
\hline \multicolumn{1}{|c|}{ Land } & $\begin{array}{c}\text { Match } \\
\text { (TP) }\end{array}$ & $\begin{array}{c}\text { Not Match } \\
(\text { FN) }\end{array}$ & $\begin{array}{c}\text { Total } \\
\text { Data }\end{array}$ \\
\hline $\begin{array}{l}\text { Kec. } \\
\text { Bambanglipuro }\end{array}$ & 6 & 2 & 8 \\
\hline Kec. Bantul & 8 & 0 & 8 \\
\hline
\end{tabular}

\section{CONCLUSION}

Based on the results, it can be concluded that a decision support system for determining plants that are suitable for the land has been successfully built. This system uses the Profile Matching method with two aspects, namely the physical aspect of the soil and the chemical aspect of the soil as well as 13 criteria. The physical aspect of the soil has criteria consisting of temperature, rainfall, humidity, drainage, texture, slope, erosion, and inundation. The chemical aspects of the soil consist of clay cation exchange capacity, base saturation, $\mathrm{pH} \mathrm{H} 2 \mathrm{O}$, organic $\mathrm{C}$ and alkalinity. This system can provide plant recommendations for a land in the form of ranking based on the final value of each alternative plant. The higher the final value of the alternative plant, the more suitable it will be with the land.

Table 10. Calculation results of precision, recall, and accuracy

\begin{tabular}{|l|c|c|c|}
\hline \multicolumn{1}{|c|}{ Land } & Precision & Recall & Accuracy \\
\hline $\begin{array}{l}\text { Kec. } \\
\text { Bambanglipuro }\end{array}$ & $100 \%$ & $75 \%$ & $75 \%$ \\
\hline Kec. Bantul & $100 \%$ & $100 \%$ & $100 \%$ \\
\hline Kec. Banguntapan & $100 \%$ & $75 \%$ & $75 \%$ \\
\hline Kec. Dlingo & $100 \%$ & $75 \%$ & $75 \%$ \\
\hline Kec. Imogiri & $100 \%$ & $62.5 \%$ & $62.5 \%$ \\
\hline Kec. Jetis & $100 \%$ & $62.5 \%$ & $62.5 \%$ \\
\hline Kec. Kasihan & $100 \%$ & $75 \%$ & $75 \%$ \\
\hline Kec. Kretek & $100 \%$ & $100 \%$ & $100 \%$ \\
\hline Kec. Pajangan & $100 \%$ & $100 \%$ & $100 \%$ \\
\hline Kec. Pandak & $100 \%$ & $75 \%$ & $75 \%$ \\
\hline
\end{tabular}




\begin{tabular}{|l|c|c|c|}
\hline Kec. Piyungan & $100 \%$ & $62.5 \%$ & $62.5 \%$ \\
\hline Kec. Pleret & $100 \%$ & $62.5 \%$ & $62.5 \%$ \\
\hline Kec. Pundong & $100 \%$ & $75 \%$ & $75 \%$ \\
\hline Kec. Sanden & $100 \%$ & $75 \%$ & $75 \%$ \\
\hline Kec. Sedayu & $100 \%$ & $100 \%$ & $100 \%$ \\
\hline Kec. Sewon & $100 \%$ & $75 \%$ & $75 \%$ \\
\hline Kec. Srandakan & $100 \%$ & $75 \%$ & $75 \%$ \\
\hline \multicolumn{1}{|c|}{ Average } & $100 \%$ & $77.94 \%$ & $77.94 \%$ \\
\hline
\end{tabular}

[4] BPT, Petunjuk Teknis Analisis Kimia Tanah, Tanaman, Air dan Pupuk, no. 2. 2009.

[5] Y. Yanuari, M. G. Husada, and D. B. Utami, "Aplikasi Rekomendasi Jenis Tanaman Pangan Menggunakan Metode Simple Additive Weighting (SAW)," JOINTECS (Journal Inf. Technol. Comput. Sci., vol. 3, no. 1, 2018.

[6] W. N. Adila, R. Regasari, and H. Nurwasito, "Sistem Pendukung Keputusan (SPK) Pemilihan Tanaman Pangan Pada Suatu Lahan Berdasarkan Kondisi Tanah Dengan Metode ELECTRE," J. Pengemb. Teknol. Inf. dan Ilmu Komput. Univ. Brawijaya, vol. 2, no. 5, 2018.

The results of the Profile matching method evaluation show an accuracy rate of $77.94 \%$, a recall rate of $77.94 \%$, and a precision of $100 \%$. The results of the evaluation of the Profile Matching method show that the system can be used to recommend plants that are suitable for the land.

\section{REFERENCES}

[1] T. Y. Widiyanti, T. B. Adji, and I. Hidayah, "The Social Engagement to Agricultural Issues using Social Network Analysis," IJID (International Journal on Informatics for Dev., vol. 10, no. 1, pp. 1-7, Jun. 2021.

[2] Kusrini, "Konsep Dan Aplikasi Sistem Pendukung Keputusan,” Penerbit Andi. 2007.

[3] D. Djaenudin, M. H., S. H., and A. Hidayat, Petunjuk Teknis Evaluasi Lahan untuk Komoditas Pertanian. 2011.

[7] E. Turban, J. E. Aronson, and Ting-Peng Liang, Decision Support Systems and Intelligent Systems. 2003.

[8] P. Yunita, "SPK Pemilihan Bantuan Bedah Rumah pada Kelurahan Purnama Menggunakan Metode SAW," JISKA (Jurnal Inform. Sunan Kalijaga), vol. 4, no. 1, 2019.

[9] A. Setiawan, Sutardi, and Tajidun, "SPK Penilaian Dan Pemberian Bonus Salesman Pada Masyarakat Kendari Menggunakan Profile Matching," semanTIK, vol. 3, no. 1, 2017.

[10] M. E. Iswanto, M. U. Siregar, S. 'Uyun, and M. T. Nuruzzaman, "Recommender systems for specializing new students in the K-13 curriculum using the profile matching, SAW, and a combination of both," J. Teknol. dan Sist. Komput., vol. 9, no. 2, pp. 96-105, Apr. 2021 